\title{
Use of Persistent Analogs of Abscisic Acid as Palliatives against Salt-stress Induced Damage in Citrus Plants
}

\author{
Vicent Arbona, ${ }^{1}$ María F. López-Climent, ${ }^{1}$ Jalel Mahouachi, ${ }^{2}$ \\ Rosa M. Pérez-Clemente, ${ }^{1}$ Suzanne R. Abrams, ${ }^{3}$ and \\ Aurelio Gómez-Cadenas ${ }^{1 *}$
}

\begin{abstract}
${ }^{1}$ Departamento de Ciencias Experimentales, Universitat Jaume I, Campus Riu Sec, E-12071 Castelló, Spain; ${ }^{2}$ Departamento de Suelos y Riegos, Instituto Canario de Investigaciones Agrarias, Apdo 60, E-38200, La Laguna Tenerife, Spain; ${ }^{3}$ Plant Biotechnology Institute, National Research Council of Canada, 110 Gymnasium Place, Saskatoon, Saskatchewan S7N 0W9, Canada
\end{abstract}

\begin{abstract}
The effectiveness of several abscisic acid (ABA) analogs as palliatives against salt stress in intact citrus plants has been tested in this work. The effect of ABA, 8'-methylene ABA, 8'-acetylene ABA, ABA methyl ester, $8^{\prime}$-methylene ABA methyl ester, and 8 -acetylene ABA methyl ester on citrus responses to salt stress was studied on 2-year-old grafted plants. Leaf abscission, chloride accumulation, ethylene production, and net photosynthetic rate were the parameters used to characterize the performance of plants under stress. Data indicate that 8'-methylene ABA was the most effective compound in delaying the deleterious effects of high
\end{abstract}

\section{INTRODUCTION}

Citrus can be classified as a very salinity-sensitive crop (Levy and Syvertsen 2004; Storey and Walker

Received 5 April 2005; accepted 3 August 2005; online publication 28 February 2006

*Corresponding author; e-mail: cadenas@exp.uji.es salinity on citrus plants. Its regular application reduced leaf chloride concentration, ethylene production, and leaf abscission. Furthermore, it delayed the depletion of $\mathrm{CO}_{2}$ assimilation under these adverse conditions. Abscisic acid and $8^{\prime}$-acetylene ABA also reduced salt-stress induced injuries in citrus, although to a lower extent. Neither ABA methyl ester nor its $8^{\prime}$-C modified analogs showed biological activity in these assays.

Key words: Abscisic acid; Chloride accumulation; Citrus; Ethylene production; Leaf abscission; Photosynthetic rate; Salinity 
Aranda and others 1998), and it has been proposed that chloride absorption and hence, salt tolerance, in citrus depends to a great extent on water use (Moya and others 2003).

Salinity causes a decrease in soil osmotic potential and subsequently limits water flux to leaves and assimilation of mineral nutrients (Ruiz and others 1997). Citrus has a highly efficient osmotic adjustment system whereby accumulation of organic solutes and ions absorbed from the substrate contribute to decreased water potential in leaves and to maintenance of water flux, thereby avoiding dehydration (Gómez-Cadenas and others 1998; Maas 1993). Salinity also promotes suberization of root tissues (Walker and others 1984), visual toxicity symptoms (Chapman 1968), and eventually leaf abscission (Gómez-Cadenas and others 1998, 2002). Furthermore, chloride accumulation in citrus leaves decreases net photosynthetic rate, transpiration, and stomatal conductance and activates plant antioxidant machinery (Arbona and others 2003; Iglesias and others 2004).

Citrus plants rapidly respond to water deficit or salinity by increasing endogenous ABA levels (Gómez-Cadenas and others 1996, 1998). The functions of $\mathrm{ABA}$ in plants under stress have been well documented (see Xiong and Zhu 2003 and references therein). In particular, it has been shown that ABA causes stomatal closure and therefore decreases leaf photosynthetic rate and transpiration, which has been linked to $\mathrm{Cl}^{-}$uptake (Gómez-Cadenas and others 2002). In addition, ABA can increase the synthesis of proteins helpful for the acclimation of the plants to different stressful conditions (Sachs and Ho 1986). It has also been shown that ethylene modulates leaf abscission in citrus under water stress (GómezCadenas and others 1996) or salt stress (GómezCadenas and others 1998). In salinized citrus leaves, the increase in chloride levels has been correlated with the accumulation of 1-aminocyclopropane-1-carboxylicic acid (ACC) and its subsequent oxidation to ethylene (Gómez-Cadenas and others 1998, 2002).

To avoid the deleterious effects of salinity on citrus physiology, several approaches have recently been taken. In salinized citrus, nitrate supplementation stimulated photosynthetic activity and growth of new leaves, as well as reduced leaf abscission (Iglesias and others 2004). Exogenous ABA regularly applied to the watering solution was also effective in reducing chloride accumulation, ethylene release, and leaf abscission in citrus under salt stress (Gómez-Cadenas and others 2002).
Several analogs of ABA have been synthesized (Abrams and others 1997; Cutler and others 2000; Rose and others 1997; Todoroki and others 1995), and their role as persistent forms of ABA studied in different plant systems. Modifications in the $8^{\prime}-\mathrm{C}$ position can render analogs resistant to oxidation by ABA 8'-hydroxylase because the $8^{\prime}$-methyl group becomes less accessible to the active site of the enzyme. In this sense, one of these analogs, the 8'acetylene $\mathrm{ABA}$, has been shown to be an irreversible inhibitor of ABA 8'-hydroxylase (Cutler and others 2000). A different analog, the $8^{\prime}$-methylene $\mathrm{ABA}$, has been shown to be more effective than ABA in several biological assays (Abrams and others 1997; Qi and others 1998). The biological activity of the ABA-methyl ester has also been tested with different results. Although an effect on ABA-induced gene expression in barley aleurone protoplasts has been reported (Vandermeulen and others 1993), no effects were observed in maize roots (Hose and others 2000).

In a previous work, it was shown that exogenous ABA improved salt tolerance in citrus because of a reduction in leaf $\mathrm{Cl}^{-}$concentration (Gómez-Cadenas and others 2002). In the present work, we have tested the hypothesis that different ABA analogs could improve the physiological effect of ABA on citrus under salt stress by slowing metabolism in the plant. Therefore, we have compared the effect of ABA, ABA methyl ester, and several analogs of both compounds with modifications in the $8^{\prime}$-C-position (see Table 1) as palliatives of salt-induced damage in intact citrus plants. To characterize the effect of high salinity in citrus, leaf abscission, chloride accumulation, ethylene production, and photosynthetic rate were measured at different times. High $\mathrm{NaCl}$ concentrations (60 or $100 \mathrm{mM}$ ) were added to the watering solutions to achieve a reproducible experimental system.

\section{Materials ANd Methods}

\section{Plant Material}

Two different cultivars of citrus were used for the experiments described in this work, "Salustiana" [Citrus sinensis (L) Osbeck] and "Clementina de Nules" (Citrus reticulata Blanco). However, both cultivars were grafted in the same rootstock, Carrizo citrange (Citrus sinensis [L.] Osbeck $\times$ Poncirus trifoliata [L.] Raf). It has been previously demonstrated (Mass 1993; Storey and Walker 1999) that salt tolerance is particularly dependent on the rootstock. Two-year-old plants were obtained from a commercial nursery and transplanted to plastic containers at least one month prior to the beginning 
Table 1. Compounds Used in this Work

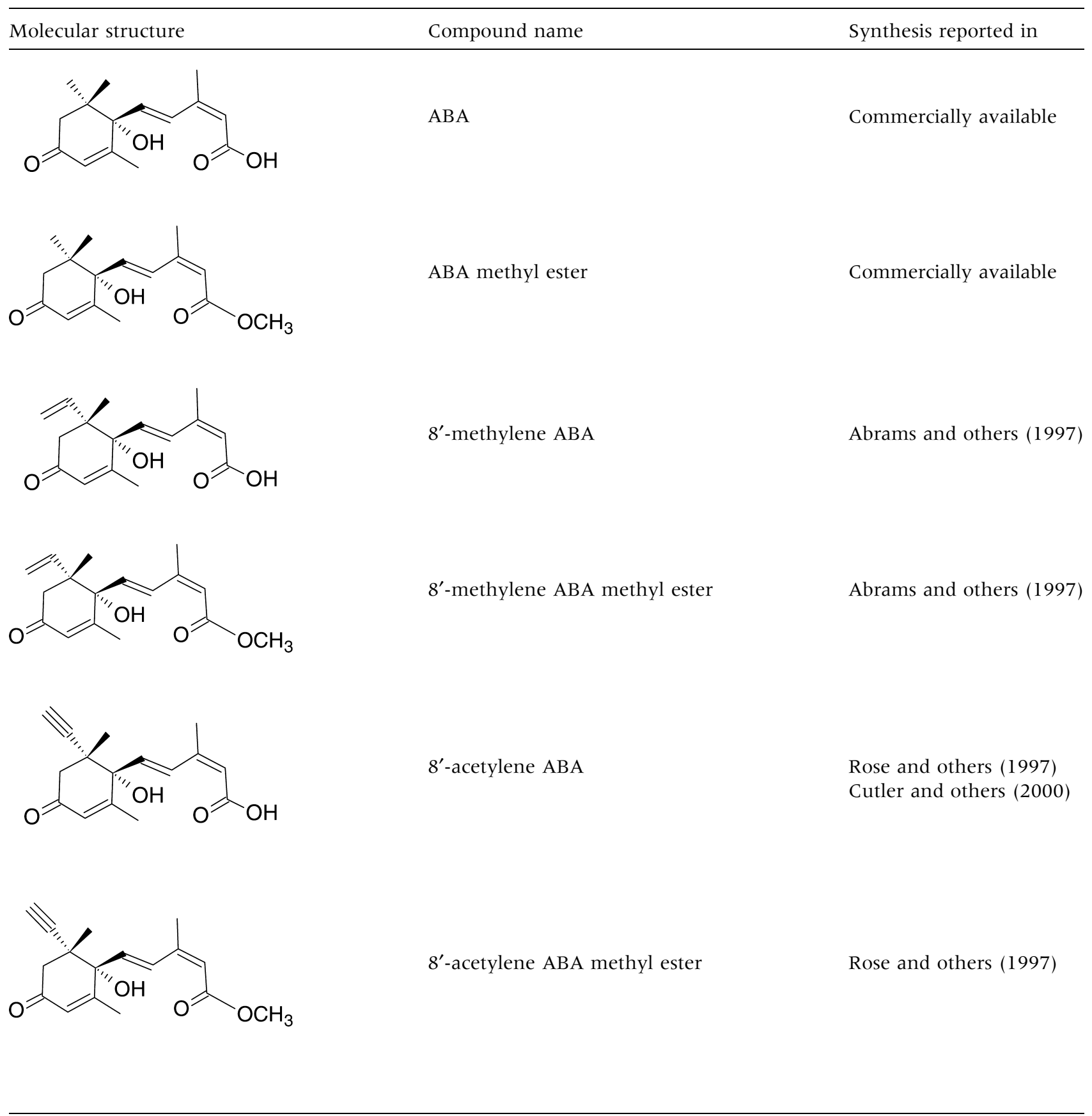

of the experiments. Plants were cultivated in a greenhouse under the following conditions: day temperature, $26^{\circ}-32^{\circ} \mathrm{C}$; night temperature, $18^{\circ}-20^{\circ} \mathrm{C}$; photoperiod, $16: 8$ (L:D) and $50 \%-95 \%$ relative humidity. Maximum photosynthetically

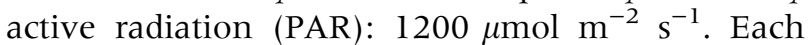
plant was watered twice a week with $400 \mathrm{ml}$ of a half-strength modified Hoagland solution (GómezCadenas and others 2002).

\section{Description of the Different Experiments.} Chemical and Salt Treatments

Two different experiments were performed. In the first experiment, the effect of ABA methyl ester and two analogs of this molecule $\left(8^{\prime}\right.$-methylene ABA methyl ester and 8'-acetylene ABA methyl ester) on citrus responses to salt stress was studied by using plants of the Salustiana cultivar grafted on 
Carrizo citrange rootstock. In a second experiment, the effect of two different analogs of ABA (8'acetylene $\mathrm{ABA}$ and $8^{\prime}$-methylene $\mathrm{ABA}$ ) was tested as palliatives against salt stress on citrus. For this, plants of "Clementina de Nules" cultivar grafted on the same rootstock (Carrizo citrange) were used.

In both cases, plants were grown in 4-l containers filled with perlite as a substrate and different blocks of 12 plants were established following a randomized design. The effect of the different ABA analogs on citrus responses were compared in each case with the effect of ABA. Therefore, for the first experiment, the blocks established were (a) control, non-treated plants; (b) salt-stressed plants not treated with any chemical; (c) salt-stressed plants treated with $\mathrm{ABA}$; (d) salt-stressed plants treated with ABA methyl ester; (e) salt-stressed plants treated with $8^{\prime}$-methylene ABA methyl ester, and (f) salt-stressed plants treated with $8^{\prime}$-acetylene ABA methyl ester. For the second experiment, five blocks of plants were established, (a), (b), and (c) were as in experiment $1,(d)$ contained salt-stressed plants treated with $8^{\prime}$-acetylene ABA, and (e) contained salt-stressed plants treated with 8'methylene ABA.

All chemicals were added to the watering solution to achieve a final concentration of $10 \mu \mathrm{M}$, and treatments were initiated 10 days before the beginning of salinization and maintained during the whole experiment. Salt stress was imposed by adding $\mathrm{NaCl}$ to the modified Hoagland solution to reach a concentration of $100 \mathrm{mM}$ for the first experiment and $60 \mathrm{mM}$ for the second one. Both experiments were repeated twice in the spring (experiment 1 in 2001 and 2002 and experiment 2 in 2003 and 2004).

In both experiments, ABA was obtained from Sigma-Aldrich (Madrid, Spain), $\mathrm{NaCl}$ from J. T. Baker (Madrid, Spain), and ABA methyl ester and the different ABA analogs were synthesized as indicated in the references shown in Table 1. Purity of the analogs was confirmed by comparison of the nuclear magnetic resonance (NMR) and mass spectra of the samples used with those values reported in the literature.

\section{Leaf Number}

The number of leaves was recorded regularly and expressed as a percentage of that present in each plant on the first day of the experiment (which was considered as a $100 \%$ ). When plants grew, newly developing leaves were only considered when they achieved half of the fully expanded size.

\section{Photosynthesis Measurements}

Net photosynthetic rate was measured with a LC-pro portable photosynthesis system (ADC Bioscientific Ltd., Hoddesdon, UK) equipped with a $6.25 \mathrm{~cm}^{2}$ standard "broad type" leaf chamber. All measurements were performed under an air-flow rate of $300 \mu \mathrm{mol} \mathrm{s}$, at ambient humidity $(60 \%-$ $80 \%)$ and $\mathrm{CO}_{2}\left(377 \pm 10 \mu \mathrm{mol} \mathrm{mol} \mathrm{m}^{-1}\right)$. Determinations were performed at 9:00 h on fully expanded leaves at $750 \mu \mathrm{mol} \mathrm{m}{ }^{-2} \mathrm{~s}^{-1}$, the minimum saturating photon flux density observed in preliminary experiments. Within the cuvette, the average temperature was $23.5^{\circ} \pm 0.8^{\circ} \mathrm{C}$ and the leaf-to-air vapor pressure deficit was $1.5 \pm 0.2 \mathrm{kPa}$.

\section{Chloride Analysis}

Analyses of chloride anions were performed as described in Gómez-Cadenas and others (1998). Briefly, plant dry tissue was incubated overnight with a mixture of glacial acetic acid and nitric acid in water. Supernatant was filtered through ash-free filter papers and then $0.5 \mathrm{ml}$ was used for the automatic titration in a chloride analyzer (model 926, Sherwood Scientific Ltd. Cambridge, UK.).

\section{Ethylene Production}

Ethylene release was measured in intermediate leaves by gas chromatography as previously described (Gómez-Cadenas and others 1996). To excise leaves from the plant, a cut was made at the base of the petiole with a razor blade. Leaves were then enclosed individually in $12-\mathrm{ml}$ tubes with the petiole submerged in $100 \mu$ l of water placed in the bottom of the tube. After $30 \mathrm{~min}$, the tube was aerated and then sealed with a silicone cap. After a $4 \mathrm{~h}$ incubation period, $1 \mathrm{ml}$ of the enclosed atmosphere was injected into a gas chromatograph (Agilent 4890D, Agilent technologies, Inc. Wilmington, DE) equipped with an activated alumina column and a flame ionization detector. The instrument was previously calibrated with known amounts of an ethylene standard.

\section{Reproducibility of the Determinations and Statistical Analyses}

Each photosynthesis determination consisted of a minimum of 15 measurements in different leaves. Chloride concentration was measured in at least four plants, with three independent extractions of each sample. Ethylene production was determined in nine leaves randomly chosen from each of the different blocks of plants. In Table 2 and Table 3 , 
Table 2. Effect of ABA, ABA Methyl Ester, 8'-Methylene ABA Methyl Ester, and 8'-Acetylene ABA Methyl Ester on Leaf Abscission in Salinized Citrus (Salustiana cultivar grafted on Carrizo citrange)

\begin{tabular}{|c|c|c|c|c|}
\hline \multirow{2}{*}{$\begin{array}{l}\text { Leaf number (\%) } \\
\text { Treatment }\end{array}$} & \multicolumn{4}{|c|}{ Time after treatment } \\
\hline & 10 days & 30 days & 45 days & 60 days \\
\hline Control, non salinized & $101.5^{\mathrm{a}}$ & $104.3^{\mathrm{b}}$ & $106.9^{\mathrm{d}}$ & $112.5^{\mathrm{d}}$ \\
\hline $\mathrm{NaCl}$ & $102.5^{\mathrm{a}}$ & $100.9^{\mathrm{ab}}$ & $53.3^{\mathrm{b}}$ & $2.5^{\mathrm{a}}$ \\
\hline $\mathrm{NaCl}+\mathrm{ABA}$ & $101.3^{\mathrm{a}}$ & $99.9^{\mathrm{b}}$ & $93.5^{\mathrm{c}}$ & $32.3^{c}$ \\
\hline $\mathrm{NaCl}+\mathrm{ABA}$ methyl ester & $101.9^{\mathrm{a}}$ & $101.0^{\mathrm{ab}}$ & $49.5^{\mathrm{b}}$ & $5.2^{\mathrm{b}}$ \\
\hline $\mathrm{NaCl}+8^{\prime}$-methylene ABA methyl ester & $100.8^{\mathrm{a}}$ & $100.4^{\mathrm{ab}}$ & $21.5^{\mathrm{ab}}$ & $3.4^{\mathrm{ab}}$ \\
\hline $\mathrm{NaCl}+8^{\prime}$-acetylene ABA methyl ester & $101.4^{\mathrm{a}}$ & $100.8^{\mathrm{ab}}$ & $11.1^{\mathrm{a}}$ & $2.8^{\mathrm{a}}$ \\
\hline
\end{tabular}

Chemicals were added to the watering solution at $10 \mu \mathrm{M}$ from day 0 and at $100 \mathrm{mM} \mathrm{NaCl}$ from day 10 . Data are means of seven independent measurements. Data within each column followed by dissimilar letters differ significantly at $p \leq 0.05$.

Table 3. Effect of ABA, ABA Methyl Ester, 8'-Methylene ABA Methyl Ester, and 8'-Acetylene ABA Methyl Ester on Leaf Chloride Concentration in Salinized Citrus (Salustiana cultivar grafted on Carrizo citrange)

Chloride concentration $(\%)$

Time after treatment

\begin{tabular}{llll}
\cline { 2 - 4 } Treatment & 10 days & 30 days & 45 days \\
\hline Control, non salinized & $0.19^{\mathrm{a}}$ & $0.19^{\mathrm{a}}$ & $0.13^{\mathrm{a}}$ \\
$\mathrm{NaCl}$ & $0.17^{\mathrm{a}}$ & $2.67^{\mathrm{c}}$ & $3.81^{\mathrm{c}}$ \\
$\mathrm{NaCl}+\mathrm{ABA}$ & $0.16^{\mathrm{a}}$ & $0.82^{\mathrm{b}}$ & $1.21^{\mathrm{b}}$ \\
$\mathrm{NaCl}+\mathrm{ABA}$ methyl ester & $0.16^{\mathrm{a}}$ & $2.52^{\mathrm{c}}$ & $3.79^{\mathrm{c}}$ \\
$\mathrm{NaCl}+8^{\prime}$-methylene ABA methyl ester & $0.21^{\mathrm{a}}$ & $2.40^{\mathrm{c}}$ & $3.52^{\mathrm{c}}$ \\
$\mathrm{NaCl}+8^{\prime}$-acetylene ABA methyl ester & $0.18^{\mathrm{a}}$ & $2.56^{\mathrm{c}}$ & $3.85^{\mathrm{c}}$
\end{tabular}

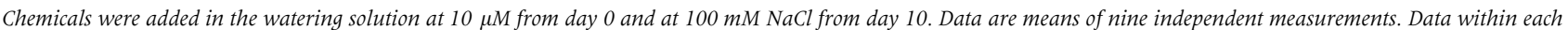
column followed by dissimilar letters differ significantly at $p \leq 0.05$.

means were compared by using the least significant difference (LSD) test $(p \leq 0.05)$. Statistical analyses were performed with StatGraphics Plus (V. 2.1.) for Windows (Statistical Graphics Corp., MD).

\section{RESUltS}

\section{Experiment 1}

Addition of $100 \mathrm{mM} \mathrm{NaCl}$ to the watering solution promoted a significant defoliation of citrus plants (Table 2). Therefore, although non-salinized plants showed no leaf drop during the period studied and, on the contrary, new ones grew, salinized plants had lost $97.5 \%$ of their leaves at the end of the experimental period. Abscisic acid treatment had an important effect in reducing salt-stress induced leaf abscission. In this way, practically all leaves remained attached to the shoot for the first 30 days of the experiment. Afterwards, leaf drop was observed, but it was clearly less dramatic than in salinized plants not treated with $\mathrm{ABA}$. Treatments with $\mathrm{ABA}$ methyl ester or its analogs modified in the $8^{\prime}$-C- position did not show any clear effect on leaf abscission under salt stress and, despite some small differences, data were comparable to those obtained in salinized plants not treated with plant growth regulators.

Chloride concentration increased with salinity exposure (Table 3). In plants treated with plant growth regulators, different results were found. ABA-treated plants showed important reductions in leaf chloride concentration (a reduction of $68.2 \%$ at the end of the experiment with respect to salinized, non-treated plants), plants treated with ABA methyl ester or its analogs showed leaf chloride concentrations similar to that observed in salinized plants not treated with any hormone.

Ethylene production (data not shown) followed a pattern similar to that observed for leaf chloride concentration and opposite to leaf abscission in all blocks of plants. Photosynthesis rate was rapidly affected by salinity (data not shown). At the end of the experimental period, levels of net $\mathrm{CO}_{2}$ assimilation were $72 \%$ lower in $\mathrm{NaCl}$-treated plants compared to controls. Abscisic acid treatment 


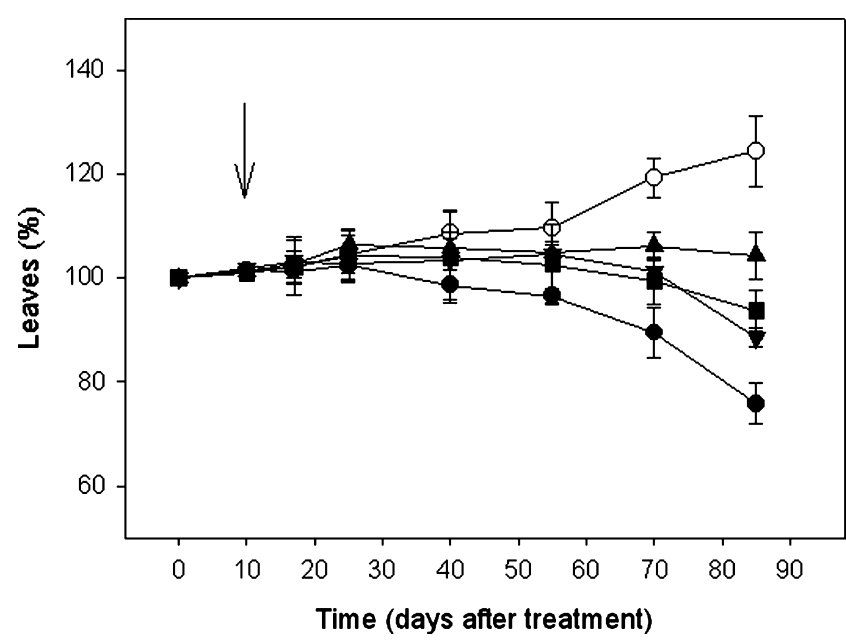

Figure 1. Effect of ABA and two ABA-analogs on leaf abscission in salinized citrus plants (Clementine cultivar grafted on Carrizo citrange). (O) Control plants; $(0)$ salinized plants; $(\mathbf{\square})$ salinized plants treated with $10 \mu \mathrm{M} \mathrm{ABA}$;

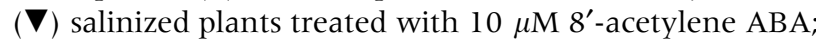
(A) salinized plants treated with $10 \mu \mathrm{M} 8^{\prime}$-methylene ABA. Data are means \pm SE of seven independent measurements. The arrow indicates the onset of salinization (60 mM NaCl).

delayed the decrease in $\mathrm{CO}_{2}$ assimilation, whereas ABA methyl ester or its analogs modified in the 8 '-C-position had no effect on this parameter in salinized plants.

\section{Experiment 2}

As shown in Figure 1, new leaves continuously grew in control plants. Therefore, at the end of the experiment, leaf number was $24 \%$ higher than at the beginning. Salinity promoted leaf abscission and the arrest of growth. In this way, at day 85, leaf number in salt-stressed plants was 39\% lower than in controls. All treatments with plant growth regulators resulted in an alleviation of leaf drop under salt stress. $\mathrm{ABA}$ and 8 -acetylene $\mathrm{ABA}$ treatments rendered similar results (at day 85, approximately $90 \%$ of leaves present at the beginning of the experiment remained attached to the shoot). Treatment with 8'-methylene ABA was even more effective, and the number of leaves present in the plants at the end of the experiment were higher than at the onset of the experimental period $(104 \%)$.

The patterns of leaf chloride concentration (Figure 2) and ethylene production (Figure 3) were very similar in this experiment. Although control plants showed basal levels for both parameters, salinity promoted a continuous increase in chloride

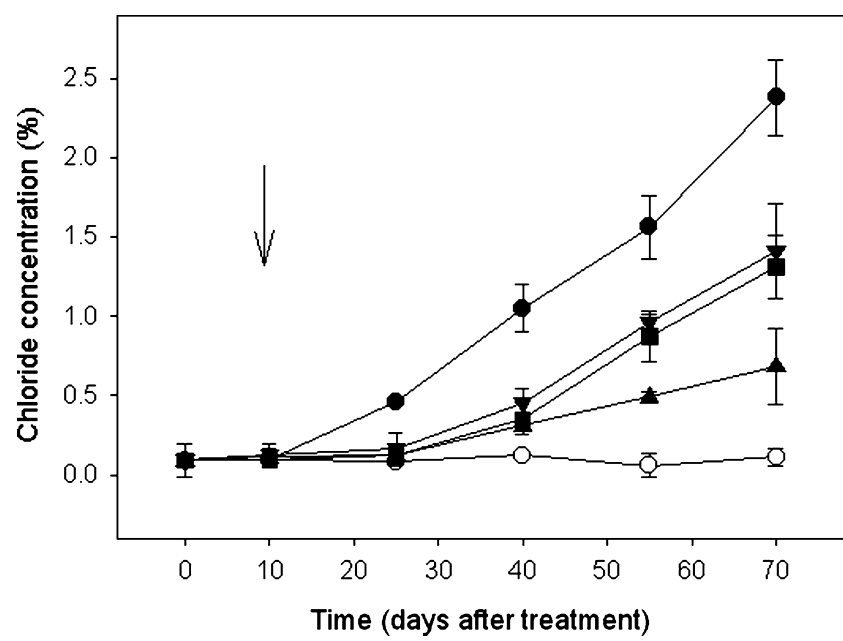

Figure 2. Effect of ABA and two ABA analogs on leaf chloride concentration in salinized citrus plants (Clementine cultivar grafted on Carrizo citrange). (○) Control plants; (О) salinized plants; (ロ) salinized plants treated with $10 \mu \mathrm{M} \mathrm{ABA} ;(\boldsymbol{\nabla})$ salinized plants treated with $10 \mu \mathrm{M}$ 8 '-acetylene ABA; $(\mathbf{A})$ salinized plants treated with $10 \mu \mathrm{M}$ 8 -methylene ABA. Data are means \pm SE of 12 independent measurements. The arrow indicates the onset of salinization (60 $\mathrm{mM} \mathrm{NaCl})$.

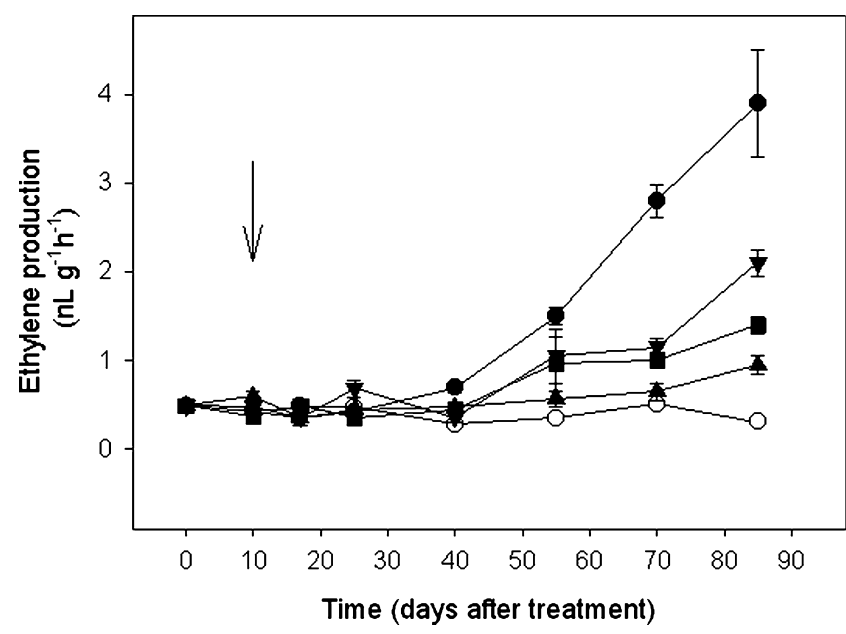

Figure 3. Effect of $\mathrm{ABA}$ and two $\mathrm{ABA}$ analogs on ethylene production in salinized citrus plants (Clementine cultivar grafted on Carrizo citrange). (O) Control plants; (-) salinized plants; (ロ) salinized plants treated with $10 \mu \mathrm{M} \mathrm{ABA} ;(\boldsymbol{\nabla})$ salinized plants treated with $10 \mu \mathrm{M}$ 8 -acetylene ABA; $(\boldsymbol{\Delta})$ salinized plants treated with $10 \mu \mathrm{M}$ $8^{\prime}$-methylene ABA. Data are means \pm SE of nine independent measurements. The arrow indicates the onset of salinization $(60 \mathrm{mM} \mathrm{NaCl})$.

concentration that was followed by the elevation of ethylene release. Treatments with $\mathrm{ABA}$ and its analogs modified in the $8^{\prime}$-C-position reduced leaf 


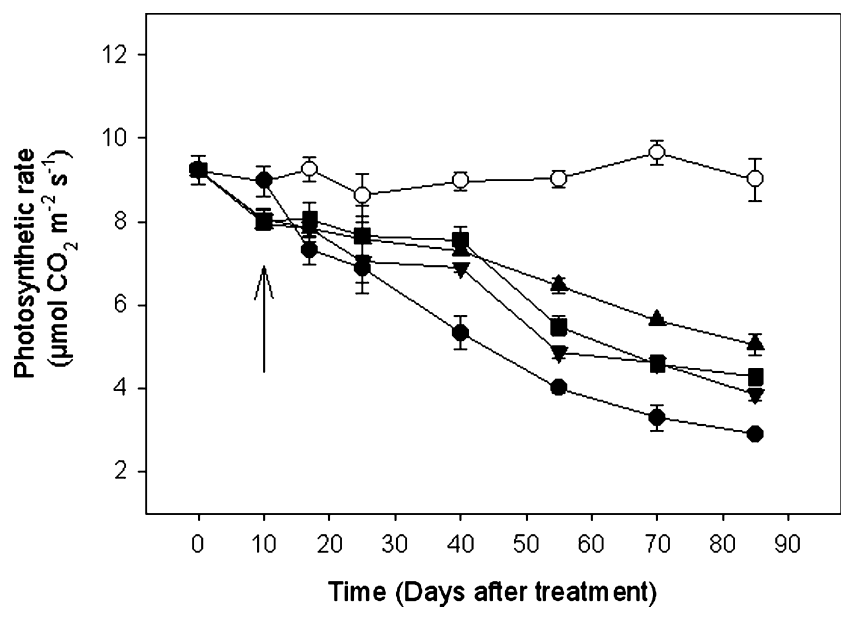

Figure 4. Effect of ABA and two ABA analogs on photosynthetic rate in salinized citrus plants (Clementine cultivar grafted on Carrizo citrange). (○) Control plants; (-) salinized plants; (घ) salinized plants treated with $10 \mu \mathrm{M} \mathrm{ABA;}(\boldsymbol{\nabla})$ salinized plants treated with $10 \mu \mathrm{M} 8^{\prime}$ acetylene ABA; $(\mathbf{\Delta})$ salinized plants treated with $10 \mu \mathrm{M} 8^{\prime}$ methylene ABA. Data are means \pm SE of 15 independent measurements. The arrow indicates the onset of salinization $(60 \mathrm{mM} \mathrm{NaCl})$.

chloride intoxication promoted by salinity. As reported for leaf abscission, the 8'-methylene ABA was the most effective product in reducing chloride concentrations in citrus leaves $(71 \%$ lower than salinized plants not treated with hormones, at day 70), although the reduction in this parameter in plants treated with $\mathrm{ABA}$ or $8^{\prime}$-acetylene $\mathrm{ABA}$ was also significant $(41 \%$ lower than salinized nontreated plants, at day 70). Ethylene release was practically parallel to the increase in leaf chloride throughout the experimental period in all groups of plants. Only at the last point of sampling did ethylene production differ from chloride concentration in ABA- and 8'-acetylene ABA-treated plants. At this point, while $\mathrm{Cl}^{-}$concentration was similar in both groups of plants, ethylene production was lower in ABA-treated plants.

The net photosynthetic rate (Figure 4) was rapidly affected by the addition of $60 \mathrm{mM} \mathrm{NaCl}$ to the watering solution. Plants under salt stress continuously reduced the $\mathrm{CO}_{2}$ assimilation rate to reach levels very low at the end of the experiment (at day 85 , reductions of $67 \%$ were found in salinized plants not treated with hormones). All hormonal treatments promoted a decrease of this parameter at day 10 (7\% in average) previous to the onset of salinization. Afterwards, $\mathrm{CO}_{2}$ assimilation decreased progressively but always remained higher than in salinized, non-treated plants. The most effective treatment in delaying the drop in photosynthesis rate under stress conditions was 8 '-methylene ABA.

\section{Discussion}

Recently, several methods to efficiently synthesize considerable quantities of 8 '-C-modified ABA analogs have been reported (Abrams and others 1997; Cutler and others 2000; Rose and others 1997). This opened the possibility of testing them in long-term experiments with crops to evaluate their putative agronomical uses. One of the analogs employed in this work, the 8'-methylene $\mathrm{ABA}$ is metabolized more slowly than $\mathrm{ABA}$ in corn cells resulting in an enhanced biological activity relative to $A B A$ (Abrams and others 1997). Moreover, 8'-methylene ABA has been shown to be more effective than ABA in inducing gene expression in Brassica napus embryos (Qi and others 1998) and its applications resemble extended pulses of ABA. The 8'-acetylene $\mathrm{ABA}$ has been shown to be an irreversible inhibitor of ABA 8'-hydroxylase (Cutler and others 2000). However, its biological effect varied in different plant systems. Although it exhibited stronger hormonal activity than ABA in inhibiting Arabidopsis thaliana seed germination, its activity was weaker than ABA in the stimulation of water flow in maize roots (Sauter and others 2002). The activity of ABA methyl ester has been discussed with contrasting results (Hose and others 2000; Sauter and others 2002; Vandermeulen and others 1993). Data presented in the present work demonstrated that $8^{\prime}$ methylene ABA has a protective effect stronger than ABA itself in intact plants of citrus cultivated under high concentrations of $\mathrm{NaCl}$. Results also show that the biological activity of $8^{\prime}$-acetylene $\mathrm{ABA}$ in this plant system was comparable to that of $\mathrm{ABA}$ and reject an effect for ABA methyl ester or its 8 -C-modified analogs as palliative treatments against salt stress in citrus.

The sensitivity of citrus to chloride ions has been demonstrated (Bañuls and others 1997; Romero-Aranda and others 1998) and its accumulation in tissues shown to negatively affect plant metabolism and physiology. Under high salinity conditions, impairments in photosynthesis and metabolism lead progressively to a loss in plant yield and performance, and finally, if the adverse conditions persist, ethylene burst triggers leaf abscission and subsequently plant death (Gómez-Cadenas and others 1998, 2002; Storey and Walker 1999). Data presented in this work show that leaf chloride accumulation, ethylene production, and abscission 
followed similar patterns during the experimental period in the different groups of plants. In this way, salinized plants not treated with plant growth regulators increased leaf chloride concentrations, and this can be directly correlated with ethylene burst and leaf abscission. The efficacy of the different hormonal treatments is clearly related to the reduction in leaf chloride build-up. Treatment with 8'-C methylene ABA resulted in the lowest accumulation of chloride, and therefore ethylene release and leaf abscission were lower. Treatments with $\mathrm{ABA}$ or $8^{\prime}-\mathrm{C}$ acetylene $\mathrm{ABA}$ promoted intermediate increases in the three parameters considered. Finally, treatments with ABA methyl ester or its analogs did not modify the pattern of chloride accumulation and therefore resulted in similar leaf drops in response to high salinity. These data seem to indicate that at least part of the effect of the longlasting ABA analogs as palliatives against salinity is due to the reduction in leaf chloride accumulation. However, specific effects of the chemicals cannot be precluded, at the view of the results on the last day of sampling. At this point, $\mathrm{Cl}^{-}$concentration was similar in ABA- and 8'-acetylene ABA-treated plants but, in contrast, ethylene production was lower in ABA-treated plants. Possible mechanisms involved in the lower $\mathrm{Cl}^{-}$uptake when $\mathrm{ABA}$ and analogs were added could be related to a reduction in transpiration or modifications in shoot/root ratio. Other agronomic approaches leading to improvements in the performance of citrus under salinity, such as nitrate applications, are based on the stimulation of plant growth and therefore in the dilution of toxic ions in the newly formed tissues (Iglesias and others 2004).

Carbon dioxide assimilation rapidly drops after the imposition of salt stress (Gómez-Cadenas and others 2002; Iglesias and others 2004), and it seems clear that photosynthesis reduction is related to leaf $\mathrm{Cl}^{-}$build-up (Bañuls and others 1997). Moreover, the disturbance in the photosynthetic system has been proposed as one of the causes of the oxidative stress induced by salinity (Arbona and others 2003). Data presented here clearly show that ABA and its $8^{\prime}$-C modified analogs are able to delay the depletion in $\mathrm{CO}_{2}$ assimilation under high salinity. Although data are not conclusive, ABA and its longlasting analogs could play a protective role for the photosynthetic machinery under stress.

Treatments with ABA methyl ester or its analogs did not modify the physiological parameters studied in this work, despite the use of concentrations identical to those employed for ABA and its analogs. This can be attributed to several factors such as lack of absorption from the substrate, impaired transport from roots to the aerial part of the plant, or reduced biological activity in citrus. Similar lack of activity has been observed for ABA methyl ester and for 8 -acetylene ABA methyl ester in the maize root system (Hose and others 2000; Sauter and others 2002).

In conclusion, $\mathrm{ABA}, 8^{\prime}-\mathrm{C}$ acetylene $\mathrm{ABA}$, and particularly $8^{\prime}-\mathrm{C}$ methylene $\mathrm{ABA}$ appeared as effective palliatives of salt-stress induced injuries in a biological system where intact woody plants were used, and the studied responses implied absorption and transport of plant growth regulators over the long term (the different parameters were recorded for more than 2 months in all the experiments). It should be pointed out that the $\mathrm{NaCl}$ concentrations used in these experiments were high. Therefore, it would be interesting to test lower $\mathrm{NaCl}$ concentrations similar to those found in the salinized aquifers and adult citrus trees. So far, the agronomic applications of ABA have been limited by its rapid catabolism and subsequent restricted biological activity. However, new long-lasting analogs could open a new scenario in the citrus industry, where other hormones such as gibberellins, auxins, and cytokinins have regularly been used in the orchards since the development of stable products. The putative applications of $\mathrm{ABA}$ analogs are not only restricted to growth improvement under stress conditions but also could be directed to regulate other aspects such as fruit set and development, which are crucial in the modern citrus industry (Gómez-Cadenas and others 2000) and are known to be under hormonal control.

\section{ACKNOWLEDGMENTS}

This work was supported by the Ministerio de Ciencia y Tecnología (Spain) and the Fundació Bancaixa/Universitat Jaume I through grants AGL2003-08502-C04-03 and P1 1B2003-05, respectively, to A.G-C.

\section{REFERENCES}

Abrams SR, Rose PA, Cutler AJ, Balsevich JJ, Bo L, and others. 1997. 8'-Methylene ABA - an effective and persistent analog of abscisic acid. Plant Physiol 114:89-97.

Arbona V, Flors V, García-Agustín P, Jacas J, Gómez-Cadenas A. 2003. Enzymatic and non-enzymatic antioxidant responses of Carrizo citrange, a salt-sensitive citrus rootstock, to different levels of salinity. Plant Cell Physiol 44:388-394.

Bañuls J, Serna MD, Legaz M, Primo-Millo E. 1997. Growth and gas exchange parameters of Citrus plants stressed with different salts. J Plant Physiol 150:194-199.

Chapman HD. 1968. "The mineral nutrition of citrus." In: Reuther W, Batchelor LD, Webber HD editors. The Citrus 
Industry, vol II Oakland, CA, USA: University of California Press. pp 127-289.

Cutler AJ, Rose PA, Squires TM, Loewen MK, Shaw AC, and others. 2000. Inhibitors of abscisic acid 8'-hydroxylase. Biochemistry 39:13614-13624.

Gómez-Cadenas A, Arbona V, Jacas J, Primo-Millo E, Talon M. 2002. Abscisic acid reduces leaf abscission and increases salt tolerance in citrus plants. J Plant Growth Regul 21: 234-240.

Gómez-Cadenas A, Mehouachi J, Tadeo FR, Primo-Millo E, Talon M. 2000. Hormonal regulation of fruitlet abscission induced by carbohydrate shortage in citrus. Planta 210:636643.

Gómez-Cadenas A, Tadeo FR, Primo-Millo E, Talon M. 1998. Involvement of abscisic acid and ethylene in the response of citrus seedlings to salt shock. Physiol Plant 103:475-484.

Gómez-Cadenas A, Tadeo FR, Talon M, Primo-Millo E. 1996. Leaf abscission induced by ethylene in water stressed intact seedlings of Cleopatra mandarin requires previous abscisic acid accumulation in roots. Plant Physiol 112:401-408.

Hose E, Steudle E, Hartung W. 2000. Abscisic acid and hydraulic conductivity of maize roots: a study using cell- and root-pressure probes. Planta 211:874-882.

Iglesias DJ, Levy Y, Gómez-Cadenas A, Tadeo FR, Primo-Millo E, and others. 2004. Nitrate improves growth in salt-stressed citrus seedlings through effects on photosynthetic activity and chloride accumulation. Tree Physiol 24:1027-1034.

Levy Y, Syvertsen J. 2004. "Irrigation water quality and salinity effects in citrus trees." In: Janick J, editor. Horticultural Reviews, vol. 30 West Sussex, UK: John Wiley and Sons. pp 37-82.

Maas EV. 1993. Salinity and citriculture. Tree Physiol 12:195-216.

Moya JL, Gómez-Cadenas A, Primo-Millo E, Talón M. 2003. Chloride absorption in salt-sensitive Carrizo citrange and salttolerant Cleopatra mandarin citrus rootstocks is linked to water use. J Exp Bot 54:825-833.

Qi Q, Rose PA, Abrams GD, Taylor DC. Abrams SR, and others. 1998. (+) - Abscisic acid metabolism, 3-ketoacyl-coenzyme A synthase gene expression, and very-long-chain monounsaturated fatty acid biosynthesis in Brassica napus embryos. Plant Physiol 117:979-987.

Romero-Aranda R, Moya JL, Tadeo FR, Legaz F, Primo-Millo E, and others. 1998. Physiological and anatomical disturbances induced by chloride salts in sensitive and tolerant citrus: beneficial and detrimental effects of cations. Plant Cell Environ 21:1243-1253.

Rose PA, Cutler AJ, Irvine NM, Shaw AC, Squires TM, and others. 1997. 8'-acetylene ABA: an irreversible inhibitor of ABA 8'-hydroxylase. Bioorganic Medicinal Chem Lett 7:25432546.

Ruiz D, Martínez V, Cerdá A. 1997. Citrus response to salinity: growth and nutrient uptake. Tree Physiol 17:141-150.

Sachs MM, Ho THD. 1986. Alteration of gene-expression during environmental-stress in plants. Annu Rev Plant Physiol Plant Mol Biol 37:363-376.

Sauter A, Abrams SR, Hartung W. 2002. Structural requirements of abscísic acid (ABA) and its impact on water flow during radial transport of $\mathrm{ABA}$ analogs through maize roots. J Plant Growth Regul 21:50-59.

Storey R, Walker RR. 1999. Citrus and salinity. Sci Hort 78:3981.

Todoroki Y, Hirai N, Koshimizu K. 1995. 8',8'-difluoro- and $8^{\prime}, 8^{\prime}, 8^{\prime}$-trifluoroabscisic acids as highly potent, long-lasting analogs of abscisic acid. Phytochemistry 38:561-568.

Vandermeulen RM, Heidekamp F, Jastorff B, Horgan R, Wang M. 1993. Effects of abscisic-acid analogs on abscisic-acid induced gene-expression in barley aleurone protoplasts. Relationship between structure and function of the abscisic-acid molecule. J Plant Growth Regul 12:13-19.

Walker RR, Sedgley M, Blesing MA, Douglas TJ. 1984. Anatomy, ultrastructure and assimilate concentrations of roots of citrus genotypes differing in ability for salt exclusion. J Exp Bot 35:1481-1494.

Xiong L, Zhu JK. 2003. Regulation of abscisic acid biosynthesis. Plant Physiol 133:29-36. 